Original Article

\title{
RP-HPLC METHOD DEVELOPMENT AND VALIDATION FOR THE COMBINATION OF IMIQUIMOD AND SALICYLIC ACID
}

\author{
ANKITA SHARMA ${ }^{*}$, INDER KUMAR ${ }^{2}$, KARAN RANA ${ }^{3}$
}

${ }^{1 *}$ Department of Pharmaceutical Chemistry, Abhilashi College of Pharmacy, Nerchwok, Mandi, HP, India, ${ }^{2}$ Department of Pharmaceutics, School of Pharmacy, Abhilashi University, Mandi, HP, India, ${ }^{3}$ Quality Control Executive, Complex Pharma, Karnal, Haryana, India Email: ankitasharma.anks@gmail.com

Received: 19 May 2020, Revised and Accepted: 14 Jul 2020

\section{ABSTRACT}

Objective: The present study was undertaken to develop and validate an RP-HPLC method for the combination of imiquimod and salicylic acid

Methods: The method was carried out on Nucleodur C18 (250 mm $\times 4.6 \mathrm{~mm}$ I.D., $5 \mu \mathrm{m}$ ) using low-pressure gradient elution mode. The mobile phase was used as $30 \mathrm{M}$ potassium dihydrogen phosphate and acetonitrile $(45: 55) \mathrm{pH} 6.5$ adjusted using ortho-phosphoric acid. The concentration of solvents was $1-20 \mu \mathrm{g} / \mathrm{ml}$ and the volume of injection was $20 \mathrm{mcl}$ with the flow rate of $1.0 \mathrm{ml} / \mathrm{min}$. The absorption maxima of salicylic acid and imiquimod were found $234 \mathrm{~nm}$ and $226 \mathrm{~nm}$, respectively.

Results: The method was validated and showed the linearity greater than $0.99 \%$ and with precision (RSD\%<1). The limit of detection (LOD) and limit of quantification (LOQ) of salicylic acid was found to be $0.09756 \mu \mathrm{g} / \mathrm{ml}$ and $0.2956 \mu \mathrm{g} / \mathrm{ml}$, respectively, and imiquimod was found to be $0.044031 \mu \mathrm{g} / \mathrm{ml}$ and $0.13334 \mu \mathrm{g} / \mathrm{ml}$, respectively.

Conclusion: The method developed in the present study was found to be sensitive, specific, and can be applied for the simultaneous estimation of imiquimod and salicylic acid.

Keywords: Imiquimod, Salicylic acid, Reverse-phase high-performance liquid chromatography (RP-HPLC), Validation, International council for harmonization (ICH)

(c) 2020 The Authors. Published by Innovare Academic Sciences Pvt Ltd. This is an open access article under the CC BY license (http://creativecommons.org/licenses/by/4.0/) DOI: http://dx.doi.org/10.22159/ijpps.2020v12i9.38382. Journal homepage: https://innovareacademics.in/journals/index.php/ijpps.

\section{INTRODUCTION}

Imiquimod is chemically 1 -(2-methyl propyl)-1H-imidazo [4, 5-c] quinolin-4-amine, which is a novel synthetic compound that is a member of the imidazoquinolone family of drugs [1]. The molecular formula of imiquimod is $\mathrm{C}_{14} \mathrm{H}_{16} \mathrm{~N}_{4}$, which is a white crystalline powder and the molecular weight is $240.30 \mathrm{~g} / \mathrm{mol}$. The solubility of imiquimod is freely soluble in oleic acid and lactic acid with melting point $292-294{ }^{\circ} \mathrm{C}$ and $\mathrm{pKa}$ value 2.7 . Imiquimod is an immune response modifiers use in the treatment for external genital warts by the mechanism response modifier that acts as a toll-like receptor 7 agonists. It does not kill the viruses that cause warts directly, however, also used to treat skin problems of face and scalp that is called actinic keratoses and also for various skin cancers called superficial basal cell carcinoma. In a present-day commercially available as Aldara ${ }^{\circledR} 5 \%$ imiquimod cream, approved by U. S. Food and Drug Administration ("FDA") in 1997 [2-4].

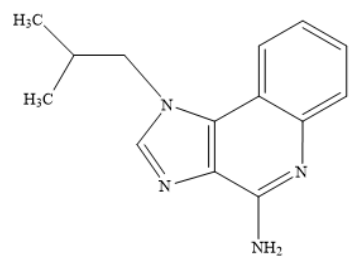

Fig. 1: Chemical structure of imiquimod

Salicylic acid (from latin salix, willow tree, from the bark of which the substance used to be obtained) is a monohydroxybenzoic acid, a type of phenolic acid and a beta hydroxy acid. Salicylic acid has the formula $\mathrm{C}_{6} \mathrm{H}_{4}(\mathrm{OH}) \mathrm{COOH}$, where the $\mathrm{OH}$ group is ortho to the carboxyl group and is poorly soluble in water $\left(2 \mathrm{~g} / \mathrm{l}\right.$ at $\left.20^{\circ} \mathrm{C}\right)$.
Aspirin (acetylsalicylic acid or ASA) can be prepared by the esterification of the phenolic hydroxyl group of salicylic acid with the acetyl group from acetic anhydride or acetyl chloride. The compound is white crystalline powder and the molecular weight is $138.12 \mathrm{~g} / \mathrm{mol}$. The solubility of salicylic acid is good in ether, $\mathrm{CCl}_{4}$ benzene, propanol, acetone, ethanol, oil of turpentine, toluene $[5,6]$. It shows its anti-inflammatory action by suppressing the activity of cyclooxygenase (COX), an enzyme that is responsible for the production of pro-inflammatory mediators such as the prostaglandins [7]. Salicylic acid also has its anti-acne action [8] Chemical structure of salicylic acid is given below:<smiles>O=C(O)c1ccccc1O</smiles>

Fig. 2: Chemical structure of salicylic acid

Simultaneously steps were taken for these two drugs successfully. Therefore it was thought to develop an accurate and rapid RP-HPLC method for simultaneous estimation of the combination of imiquimod and salicylic acid. This method was validated as per the current International Conference on Harmonization (ICH) guideline [9-11].

\section{MATERIALS AND METHODS}

Salicylic acid was procured as a gift sample from SGPTC Pvt. Ltd and imiquimod drug was obtained as a gift sample from Glenmark Pharma, Mumbai India. All other chemicals like o'phosphoric acid, potassium dihydrogen phosphate, and disodium hydrogen 
orthophosphate were used of AR grade and solvents like methanol, acetonitrile, and water were used of HPLC grade

\section{Identification of standard drugs}

The identification of standard drugs was carried out by melting point study, infrared spectroscopic study, and solubility study.

\section{Rp-hplc method}

\section{Selection of detection wavelength}

A known concentration of $10 \mu \mathrm{g} / \mathrm{ml}$ of salicylic acid and imiquimod were prepared in methanol and scanned in the UV region $200-400 \mathrm{~nm}$.

Selection of mobile phase and optimization of chromatographic condition

Initially, the mobile phase was tried with methanol: water acetonitrile: water, acetonitrile: water: methanol and then finally with phosphate buffer: acetonitrile: at various $\mathrm{pH}$ conditions. The following optimized parameters were used as a final method for the simultaneous estimation of salicylic acid and imiquimod.

\section{Chromatographic condition}

In the optimized parameters, the stationary phase was Nucleodur C18 $(250 \mathrm{~mm} \times 4.6 \mathrm{~mm}$ I.D., $5 \mu \mathrm{m}$ ) using low-pressure gradient elution mode. $30 \mathrm{M}$ potassium dihydrogen phosphate and acetonitrile (45:55) pH 6.5 were used as mobile phase and $\mathrm{pH}$ were adjusted using orthophosphoric acid. The concentration of solvents was $1-20 \mu \mathrm{g} / \mathrm{ml}$, and the volume of injection was $20 \mu \mathrm{l}$ with the flow rate of $1.0 \mathrm{ml} / \mathrm{min}$. The absorption maxima of salicylic acid and imiquimod were set in $234 \mathrm{~nm}$ and $226 \mathrm{~nm}$, respectively.

\section{Standard stock solution preparation $(100 \mu \mathrm{g} / \mathrm{ml})$}

$100 \mu \mathrm{g} / \mathrm{ml}$ solution was prepared using $10 \mathrm{mg}$ of salicylic acid $1 \mathrm{mg}$ of imiquimod and about $1 \mathrm{ml}$ of diluent was added and sonicate to dissolve to make the standard solution.

\section{Preparation of calibration curve}

Different concentration was prepared $0.1 \mu \mathrm{g} / \mathrm{ml}$ to $1 \mu \mathrm{g} / \mathrm{ml}$ for imiquimod and $1 \mu \mathrm{g} / \mathrm{ml}$ to $10 \mu \mathrm{g} / \mathrm{ml}$ for salicylic acid from the standard stock solution, respectively.

\section{Validation of RP-HPLC method}

\section{Linearity}

Different concentrations of both the drugs were prepared for linearity i.e. salicylic acid $1-10 \mu \mathrm{g} / \mathrm{ml}$ and imiquimod $0.1-1 \mu \mathrm{g} / \mathrm{ml}$ $[12,13]$.

\section{Accuracy}

Recovery studies were carried out by the addition of standard drug solution at the level of $80 \%, 100 \%$, and $120 \%$ to the preanalyzed sample. Results of the recovery study were found to be within the acceptance criteria $100 \pm 10 \%$. In this method, the

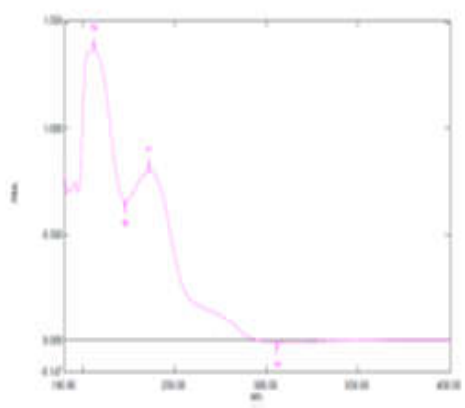

(A) known concentration of standard drug was added to the assay sample $[14,15]$

\section{Precision}

Different concentrations of both the drugs were used for intra-day and inter-day variation for six times in the same day. The concentration was $5 \mu \mathrm{g} / \mathrm{ml}$ of salicylic acid and $0.5 \mu \mathrm{g} / \mathrm{ml}$ imiquimod, and then \% RSD was calculated $[16,17]$.

\section{Limit of detection and limit of quantification}

The limit of detection can be calculated using the following equation as per ICH guidelines [18].

$$
L O D=3.3 \times N / S
$$

Where $\mathrm{N}$ is the standard deviation of the intercepts of the drug, and $\mathrm{S}$ is the slope of the corresponding calibration curve.

The limit of quantification can be calculated using the following equation as per ICH guidelines.

$$
\mathrm{LOQ}=10 \times \mathrm{N} / \mathrm{S}
$$

Where $\mathrm{N}$ is the standard deviation of the intercepts of the drug, and $\mathrm{S}$ is the slope of the corresponding calibration curve [19].

\section{Robustness}

Same samples of salicylic acid and imiquimod concentration $5 \mu \mathrm{g} / \mathrm{ml}$ and $0.5 \mu \mathrm{g} / \mathrm{ml}$ respectively by considered variation in the method parameters i.e. change in wavelength or change in flow rate, change in $\mathrm{pH}$ of the mobile phase. The change in the responses of salicylic acid and imiquimod were noted in terms of \%RSD [20]

\section{Specificity}

The specificity of the HPLC method was demonstrated by the separation of the analytes from other potential components such as impurities, degradants, or excipients. A volume of $20 \mu \mathrm{l}$ of individual ingredients and excipients solution was injected and the chromatogram was recorded [21].

\section{Ruggedness}

The ruggedness was studied by analyzing the same samples of salicylic acid and imiquimod concentration $5 \mu \mathrm{g} / \mathrm{ml}$ and $0.5 \mu \mathrm{g} / \mathrm{ml}$, respectively by changing the analyst. The change in the responses of salicylic acid and imiquimod were noted in terms of \%RSD [22].

\section{RESULTS AND DISCUSSION}

\section{Identification of imiquimod and salicylic acid}

Salicylic acid and imiquimod were observed for organoleptic properties like physical appearance, odor, and melting point. The drugs were identified with the help of UV and FTIR, and exhibited absorption maxima was $234 \mathrm{~nm}$ for salicylic acid and $226 \mathrm{~nm}$ for imiquimod when methanol was used as a solvent as mentioned in the literature (fig. 3).

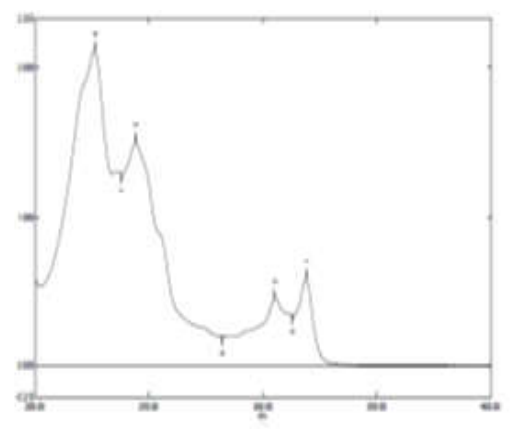

(B)

Fig. 3: UV spectrum of salicylic acid (A) and imiquimod (B) in methanol 


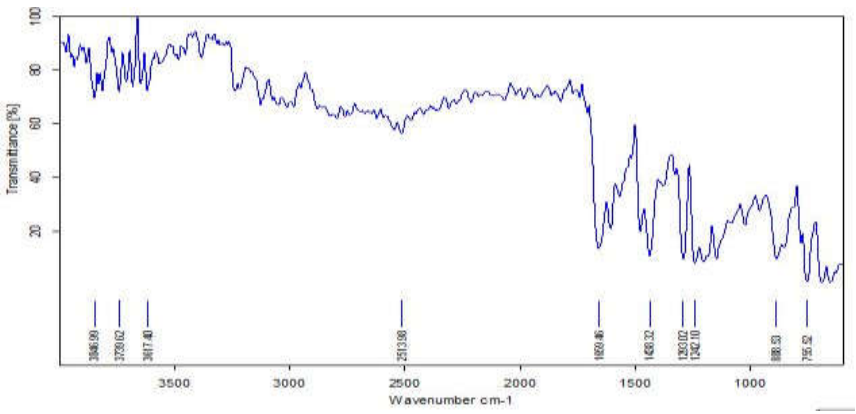

(a)

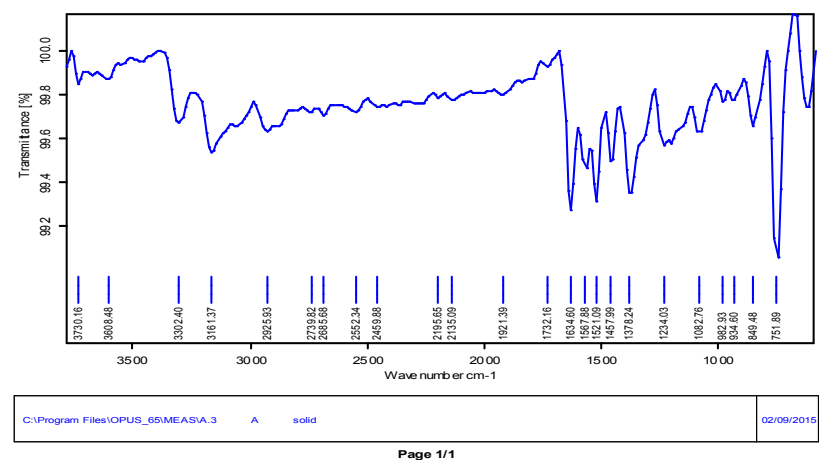

(b)

Fig. 5: FTIR spectra of (a) salicylic acid (b) imiquimod

\section{Method validation}

\section{Linearity}

The linearity of both the drugs was found within acceptance criteria. The correlation coefficient $\left(\mathrm{r}^{2}\right)$ obtained was calculated and it was found to be greater than 0.99 for salicylic acid and imiquimod is given in the below table, which is well within the acceptance criteria. Good linearity with the coefficient of correlation 0.99 indicated that the proposed method was linear within the range of 1 to $10 \mu \mathrm{g} / \mathrm{ml}$, 0.1 to $1 \mu \mathrm{g} / \mathrm{ml}$, respectively for salicylic acid and imiquimod.

Table 1: Linearity of salicylic acid

\begin{tabular}{llllll}
\hline Conc. $(\boldsymbol{\mu g} / \mathbf{m l})$ & Area1 & Area2 & Area3 & Mean & SD \\
\hline 1 & 55346 & 55051 & 55866 & 55421 & 412.6439 \\
2 & 94156 & 94907 & 94550 & 94537.67 & 375.6519 \\
3 & 129106 & 125734 & 124812 & 126550.7 & 2260.491 \\
4 & 162548 & 165085 & 167974 & 165202.3 & 2714.902 \\
5 & 187989 & 189886 & 194048 & 190641 & 30.744562 \\
6 & 230434 & 236106 & 231690 & 232743.3 & 1.786234 \\
7 & 267238 & 268739 & 264993 & 266990 & 1.64338 \\
8 & 304641 & 308556 & 307314 & 306837 & 1885.274 \\
9 & 342474 & 341383 & 348660 & 344172.3 & 2000.613 \\
10 & 383247 & 388043 & 386828 & 386039.3 & 3924.53 \\
\end{tabular}

${ }^{*}$ Conc. $=$ concentration, mean $\pm \mathrm{SD}, \mathrm{n}=3, \mathrm{SD}=$ standard deviation, $\mathrm{RSD}=$ relative standard deviation

Table 2: Linearity of imiquimod

\begin{tabular}{|c|c|c|c|c|c|c|}
\hline Conc. $(\mu \mathrm{g} / \mathrm{ml})$ & Area1 & Area 2 & Area 3 & Mean & SD & \%RSD \\
\hline 0.1 & 100795 & 100900 & 100854 & 100849.7 & 52.63396 & 0.052191 \\
\hline 0.2 & 165045 & 165650 & 164071 & 164922 & 796.6536 & 0.483049 \\
\hline 0.3 & 225478 & 220799 & 227558 & 224611.7 & 3461.78 & 1.541229 \\
\hline 0.4 & 268053 & 266795 & 267947 & 267598.3 & 697.723 & 0.260735 \\
\hline 0.5 & 330441 & 336627 & 332784 & 333284 & 3123.163 & 0.937088 \\
\hline 0.6 & 395254 & 394840 & 397691 & 395928.3 & 1540.485 & 0.389082 \\
\hline 0.7 & 468121 & 469870 & 463485 & 467158.7 & 3299.488 & 0.706288 \\
\hline 0.8 & 522375 & 524480 & 525548 & 524134.3 & 1614.496 & 0.308031 \\
\hline 0.9 & 595412 & 595953 & 595245 & 595536.7 & 370.0977 & 0.062145 \\
\hline 1 & 655536 & 652236 & 651048 & 652940 & 2325.349 & 0.356135 \\
\hline
\end{tabular}

${ }^{*}$ Conc. $=$ concentration, mean $\pm \mathrm{SD}, \mathrm{n}=3, \mathrm{SD}=$ standard deviation, $\mathrm{RSD}=$ relative standard deviation 

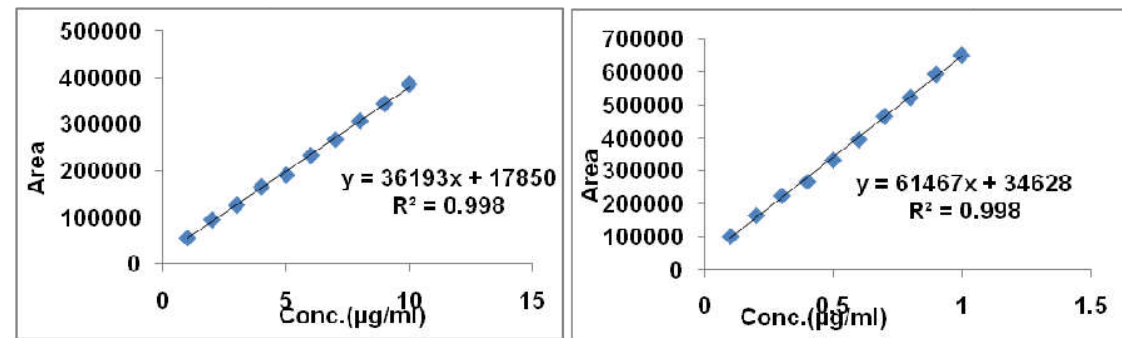

Fig. 6: Average linearity of salicylic acid (left) and imiquimod (right)

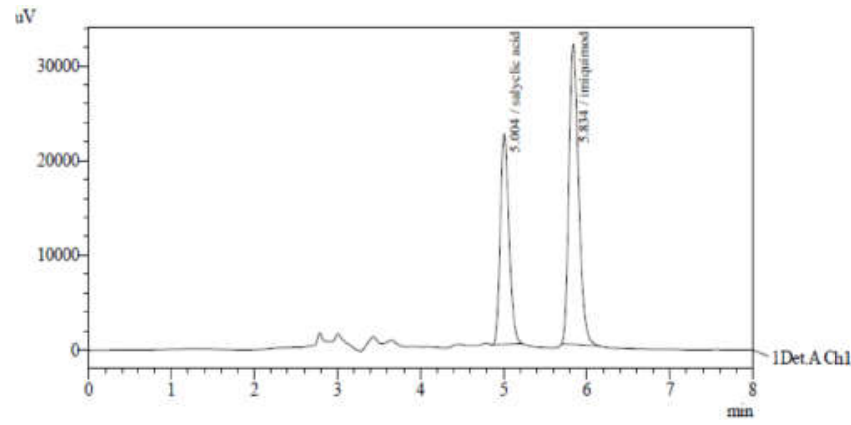

Fig. 7: Chromatogram of salicylic acid and imiquimod $(4 \mu \mathrm{g} / \mathrm{ml}$ and $0.4 \mu \mathrm{g} / \mathrm{ml})$

Table 3: Accuracy results of salicylic acid and imiquimod

\begin{tabular}{|c|c|c|c|c|c|c|c|}
\hline \multicolumn{8}{|c|}{ Accuracy results of salicylic acid } \\
\hline Conc. level & Area & Mean & Amount added & Amount recovered & \% Recovery & SD & \%RSD \\
\hline \multirow[t]{3}{*}{$80 \%$} & 167045 & 165052.66 & $4 \mu \mathrm{g} / \mathrm{ml}$ & 4.12 & 103.055 & & \\
\hline & 163972 & & $4 \mu \mathrm{g} / \mathrm{ml}$ & 4.03 & 100.932 & 2172.9 & 1.3165 \\
\hline & 164141 & & $4 \mu \mathrm{g} / \mathrm{ml}$ & 4.04 & 101.049 & & \\
\hline \multirow[t]{3}{*}{$100 \%$} & 183748 & 184728.33 & $5 \mu \mathrm{g} / \mathrm{ml}$ & 4.58 & 91.674 & & \\
\hline & 185458 & & $5 \mu \mathrm{g} / \mathrm{ml}$ & 4.63 & 92.619 & 882.13 & 0.4775 \\
\hline & 184979 & & $5 \mu \mathrm{g} / \mathrm{ml}$ & 4.61 & 92.354 & & \\
\hline \multirow[t]{3}{*}{$120 \%$} & 215834 & 217098.66 & $6 \mu \mathrm{g} / \mathrm{ml}$ & 5.47 & 91.170 & & \\
\hline & 216921 & & $6 \mu \mathrm{g} / \mathrm{ml}$ & 5.50 & 91.671 & 1362.2 & 0.6275 \\
\hline & 218541 & & $6 \mu \mathrm{g} / \mathrm{ml}$ & 5.54 & 92.417 & & \\
\hline \multicolumn{8}{|c|}{ Accuracy results of imiquimod } \\
\hline Conc. level & Area & Mean & Amount added & Amount recovered & \% Recovery & SD & \%RSD \\
\hline \multirow[t]{3}{*}{$80 \%$} & 261795 & 261930.33 & $0.4 \mu \mathrm{g} / \mathrm{ml}$ & 0.369 & 92.39 & 685.89 & 0.2619 \\
\hline & 260825 & & $0.4 \mu \mathrm{g} / \mathrm{ml}$ & 0.367 & 91.99 & & \\
\hline & 263171 & & $0.4 \mu \mathrm{g} / \mathrm{ml}$ & 0.371 & 92.95 & & \\
\hline \multirow[t]{3}{*}{$100 \%$} & 319439 & 321252.33 & $0.5 \mu \mathrm{g} / \mathrm{ml}$ & 0.463 & 92.67 & 1936.4 & 0.6028 \\
\hline & 321026 & & $0.5 \mu \mathrm{g} / \mathrm{ml}$ & 0.465 & 93.18 & & \\
\hline & 323292 & & $0.5 \mu \mathrm{g} / \mathrm{ml}$ & 0.469 & 93.92 & & \\
\hline \multirow[t]{3}{*}{$120 \%$} & 375617 & 375861 & $0.6 \mu \mathrm{g} / \mathrm{ml}$ & 0.555 & 92.45 & 1236.2 & 0.3289 \\
\hline & 377201 & & $0.6 \mu \mathrm{g} / \mathrm{ml}$ & 0.557 & 92.88 & & \\
\hline & 374765 & & $0.6 \mu \mathrm{g} / \mathrm{ml}$ & 0.553 & 92.22 & & \\
\hline
\end{tabular}

*Conc. = concentration, mean $\pm \mathrm{SD}, \mathrm{n}=3, \mathrm{SD}=$ standard deviation, $\mathrm{RSD}=$ relative standard deviation

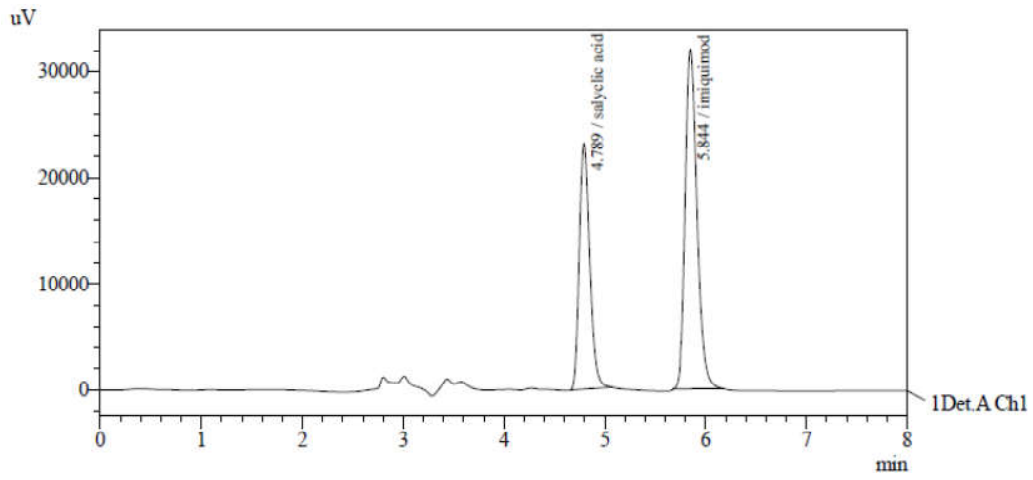

Fig. 8: Chromatogram of salicylic acid and imiquimod (80\%) 


\section{Accuracy}

The results indicate that the recoveries are well within the acceptance range of $80-120 \%$ (table 3). The chromatogram of salicylic acid and imiquimod drugs at level $80 \%$ was shown in fig. 8 .

\section{Precision}

The \%RSD for the area of six replicate injections was found to be within the specified limits i.e. for salicylic acid, it was $0.742393 \%$ and imiquimod it was observed $0.995204 \%$. Whereas the \% RSD for intra and inter-day precision of salicylic acid and imiquimod were observed below $2 \%$ [18-20]. The low values of \% RSD indicate that the method is precise. \% RSD for interday precision and intraday precision was given below that was found to be within the specified limits.

\section{Limit of detection and limit of quantitation}

The LOD was found to be $0.09756 \mu \mathrm{g} / \mathrm{ml}$ and $0.044031 \mu \mathrm{g} / \mathrm{ml}$ for salicylic acid and imiquimod respectively and LOQ was found to be
$0.2956 \mu \mathrm{g} / \mathrm{ml}$ and $0.13334 \mu \mathrm{g} / \mathrm{ml}$ salicylic acid and imiquimod respectively which showed that sensitivity of the method was high.

\section{Robustness}

The Percentage of RSD should not be more than 2. The \%RSD obtained for change of flow rate, change in wavelength, and $\mathrm{pH}$ variation in the mobile phase was found to be below 2 , which was within the acceptance criteria. Hence the method was robust.

\section{Ruggedness}

The results were found within a specified limit, \% RSD was less than 2. Data are tabulated in table 9 and fig. 10.

\section{Specificity}

Specificity of salicylic acid and imiquimod are shown in fig. 11 and table 10 . All the data were within limits. \%RSD of salicylic acid in specificity was observed $0.186425 \%$ and for imiquimod, it was $0.384456 \%$.

Table 4: Repeatability of salicylic acid and imiquimod

\begin{tabular}{lllll}
\hline S. No. & Salicylic acid & & Imiquimod & \\
\cline { 2 - 5 } & Conc. $(\boldsymbol{\mu g} / \mathbf{m l})$ & Area & Conc. $(\boldsymbol{\mu g} / \mathbf{m l})$ & Area \\
\hline 1 & 5 & 180729 & 0.5 & 312844 \\
2 & 5 & 180281 & 0.5 & 318685 \\
3 & 5 & 181842 & 0.5 & 311867 \\
4 & 5 & 182989 & 0.5 & 310441 \\
5 & 5 & 183886 & 0.5 & 316627 \\
6 & 5 & 182048 & 0.5 & 312784 \\
Mean & & 181962.5 & Mean & 313874.7 \\
Standard Deviation & 1350.877 & Standard Deviation & 3123.692 \\
\%RSD & & 0.742393 & \%RSD & 0.995204 \\
\hline
\end{tabular}

*Mean for six independent analysis, mean \pm SD, $n=6$, Conc. = concentration, $R S D=$ relative standard deviation

Table 5: Intraday and intraday precision of salicylic acid and imiquimod

\begin{tabular}{|c|c|c|c|c|}
\hline \multicolumn{5}{|c|}{ Intraday precision } \\
\hline \multirow[t]{2}{*}{ S. No. } & \multicolumn{2}{|l|}{ Salicylic acid } & \multicolumn{2}{|l|}{ Imiquimod } \\
\hline & Conc. $(\mu \mathrm{g} / \mathrm{ml})$ & Area & Conc. $(\mu \mathrm{g} / \mathrm{ml})$ & Area \\
\hline 1 & 5 & 194588 & 0.5 & 371303 \\
\hline 2 & 5 & 194165 & 0.5 & 366835 \\
\hline 3 & 5 & 195142 & 0.5 & 369995 \\
\hline 4 & 5 & 194057 & 0.5 & 370772 \\
\hline 5 & 5 & 195544 & 0.5 & 368306 \\
\hline 6 & 5 & 194999 & 0.5 & 369934 \\
\hline Mean & & 194749.2 & Mean & 313874.7 \\
\hline Standa & tion & 582.2053 & Standard Deviation & 3123.692 \\
\hline$\%$ RSD & & 0.298951 & $\%$ RSD & 0.995204 \\
\hline \multicolumn{5}{|c|}{ Interday precision } \\
\hline \multirow[t]{2}{*}{ S. No. } & \multicolumn{2}{|l|}{ Salicylic acid } & \multicolumn{2}{|l|}{ Imiquimod } \\
\hline & Conc. $(\mu \mathrm{g} / \mathrm{ml})$ & Area & & Conc. $(\mu \mathrm{g} / \mathrm{ml})$ \\
\hline 1 & 5 & 192990 & 1 & 5 \\
\hline 2 & 5 & 193563 & 2 & 5 \\
\hline 3 & 5 & 193229 & 3 & 5 \\
\hline 4 & 5 & 193825 & 4 & 5 \\
\hline 5 & 5 & 193199 & 5 & 5 \\
\hline 6 & 5 & 193807 & 6 & 5 \\
\hline \multicolumn{2}{|c|}{ Mean } & 193435.5 & Mean & 369890.8 \\
\hline \multicolumn{2}{|c|}{ Standard Deviation } & 347.2819 & Standard Deviation & 2046.481 \\
\hline \multicolumn{2}{|c|}{$\%$ RSD } & 0.179534 & $\%$ RSD & 0.553266 \\
\hline
\end{tabular}

*Mean for six independent analysis, mean \pm SD, n=6, RSD = relative standard deviation

Table 6: Limit of detection and quantitation

\begin{tabular}{|c|c|c|c|c|c|c|c|c|}
\hline API & parameter & Linearity 1 & Linearity 2 & Linearity 3 & Intercept SD & Slope mean & LOD & LOQ \\
\hline \multirow{2}{*}{ Salicylic acid } & Intercept & 18267 & 19774 & 17719 & 1064.14112 & 35992.3333 & 0.09756 & 0.2956 \\
\hline & Slope & 35900 & 35722 & 36355 & & & $\mu \mathrm{g} / \mathrm{ml}$ & $\mu \mathrm{g} / \mathrm{ml}$ \\
\hline \multirow[t]{2}{*}{ Imiquimod } & Intercept & 34160 & 34149 & 35575 & 820.144499 & 61466.3333 & 0.044031 & 0.13334 \\
\hline & Slope & 61543 & 61575 & 61281 & & & $\mu \mathrm{g} / \mathrm{ml}$ & $\mu \mathrm{g} / \mathrm{ml}$ \\
\hline
\end{tabular}

${ }^{*}$ mean $\pm \mathrm{SD}, \mathrm{n}=3, \mathrm{LOD}=$ limit of detection, $\mathrm{LOQ}=$ limit of quantitation 


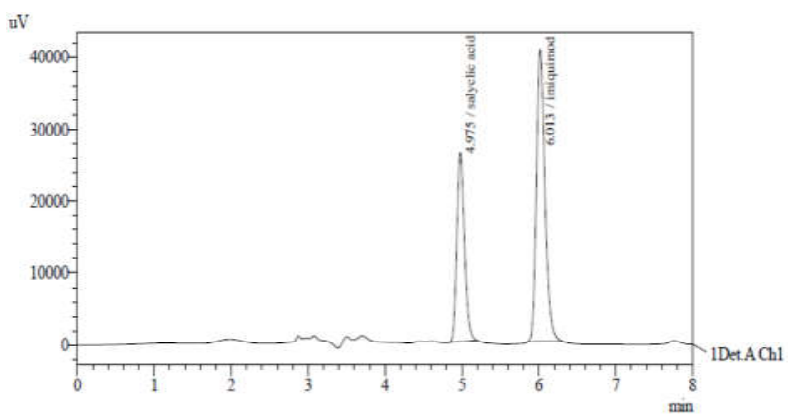

Fig. 9: Chromatogram of repeatability of salicylic acid and imiquimod

Table 7: Robustness of salicylic acid and imiquimod at different flow rates and column temperature

\begin{tabular}{|c|c|c|c|c|c|c|}
\hline \multicolumn{7}{|c|}{ Change in flow rates } \\
\hline \multirow{3}{*}{ Conc. $(\mu \mathrm{g} / \mathrm{ml})$} & \multirow{2}{*}{\multicolumn{2}{|c|}{$\begin{array}{l}0.690 \mathrm{ml} / \mathrm{min} \\
\text { Area }\end{array}$}} & \multirow{2}{*}{\multicolumn{2}{|c|}{$\begin{array}{l}0.700 \mathrm{ml} / \mathrm{min} \\
\text { Area }\end{array}$}} & \multicolumn{2}{|l|}{$0.710 \mathrm{ml} / \mathrm{min}$} \\
\hline & & & & & Area & \\
\hline & Salicylic acid & Imiquimod & Salicylic acid & Imiquimod & Salicylic acid & Imiquimod \\
\hline $5,0.5$ & 185355 & 336750 & 185716 & 331298 & 179209 & 322635 \\
\hline $5,0.5$ & 186835 & 331907 & 185978 & 327514 & 180008 & 319692 \\
\hline $5,0.5$ & 184881 & 331433 & 185234 & 332858 & 181071 & 323943 \\
\hline Mean & 185690.333 & 333363.33 & 185642.7 & 330556.7 & 180096 & 322090 \\
\hline SD & 1019.24743 & 2942.4993 & 377.3822 & 2748.048 & 934.114 & 2177.273 \\
\hline$\%$ RSD & 0.54889634 & 0.8826704 & 0.203284 & 0.831339 & 0.518676 & 0.675983 \\
\hline \multicolumn{7}{|c|}{ Change in column temperature } \\
\hline \multirow[t]{3}{*}{ Conc. $(\mu \mathrm{g} / \mathrm{ml})$} & $35^{\circ} \mathrm{C}$ & & $35^{\circ} \mathrm{C}$ & & $35^{\circ} \mathrm{C}$ & \\
\hline & Area & & Area & & Area & \\
\hline & Salicylic acid & Imiquimod & Salicylic acid & Imiquimod & Salicylic acid & Imiquimod \\
\hline $5,0.5$ & 183450 & 326827 & 189534 & 366900 & 190840 & 366438 \\
\hline $5,0.5$ & 182884 & 325182 & 194165 & 366835 & 193563 & 366114 \\
\hline $5,0.5$ & 187570 & 326333 & 193229 & 369038 & 195142 & 369995 \\
\hline Mean & 184634.667 & 326114 & 192309.3 & 367591 & 193181.66 & 367515.7 \\
\hline SD & 2557.77742 & 844.0835 & 2448.649 & 1253.56 & 2176.2036 & 2153.268 \\
\hline$\%$ RSD & 1.38531808 & 0.258831 & 1.273286 & 0.34102 & 1.1265063 & 0.585898 \\
\hline
\end{tabular}

${ }^{*}$ Conc. $=$ concentration, mean $\pm \mathrm{SD}, \mathrm{n}=3, \mathrm{SD}=$ standard deviation, $\mathrm{RSD}=$ relative standard deviation

Table 8: Robustness of salicylic acid and imiquimod at different mobile phase ratio and different wavelength

\begin{tabular}{|c|c|c|c|c|c|c|}
\hline \multirow[t]{3}{*}{ Conc. $(\mu \mathrm{g} / \mathrm{ml})$} & \multicolumn{2}{|c|}{ Buffer: ACN 49.9:50.1 } & \multicolumn{2}{|c|}{ Buffer: ACN 50.1:49.9 } & \multicolumn{2}{|c|}{ Buffer: ACN 50:50 } \\
\hline & \multicolumn{2}{|c|}{ Area } & \multicolumn{2}{|c|}{ Area } & \multicolumn{2}{|c|}{ Area } \\
\hline & Salicylic acid & Imiquimod & Salicylic acid & Imiquimod & Salicylic acid & Imiquimod \\
\hline $5,0.5$ & 192990 & 371471 & 193807 & 370423 & 189534 & 366900 \\
\hline $5,0.5$ & 194999 & 369934 & 194057 & 370772 & 194165 & 366835 \\
\hline $5,0.5$ & 195544 & 368306 & 189264 & 368613 & 193229 & 369038 \\
\hline Mean & 194511 & 369903.7 & 192376 & 369936 & 192309.3 & 367591 \\
\hline SD & 1345.11598 & 1582.718 & 2697.968 & 1158.964 & 2448.648 & 1253.56 \\
\hline$\%$ RSD & 0.69153723 & 0.427873 & 1.402445 & 0.313288 & 1.273286 & 0.34102 \\
\hline \multicolumn{7}{|l|}{ Change in wavelength } \\
\hline \multirow[t]{3}{*}{ Conc. $(\mu \mathrm{g} / \mathrm{ml})$} & $222 \mathrm{~nm}$ & & $227 \mathrm{~nm}$ & & $232 \mathrm{~nm}$ & \\
\hline & Area & & Area & & Area & \\
\hline & Salicylic acid & Imiquimod & Salicylic acid & Imiquimod & Salicylic acid & Imiquimod \\
\hline $5,0.5$ & 167812 & 287540 & 185799 & 320120 & 147045 & 394888 \\
\hline $5,0.5$ & 168691 & 286264 & 184977 & 319351 & 147211 & 388641 \\
\hline $5,0.5$ & 167785 & 287674 & 183279 & 321442 & 146878 & 392983 \\
\hline Mean & 168096 & 287159.3 & 184685 & 320304.3 & 147044.66 & 391764.5 \\
\hline SD & 515.46192 & 778.2707 & 1285.126 & 1057.617 & 166.50025 & 4417.296 \\
\hline$\%$ RSD & 0.3066473 & 0.271024 & 0.695847 & 0.330191 & 0.11323107 & 1.127539 \\
\hline
\end{tabular}

${ }^{*}$ Conc. $=$ concentration, mean $\pm \mathrm{SD}, \mathrm{n}=3, \mathrm{ACN}=$ acetonitrile, $\mathrm{SD}=$ standard deviation, $\mathrm{RSD}=$ relative standard deviation

Table 9: Ruggedness study by analyst 1 and analyst 2

\begin{tabular}{lllll}
\hline Conc. $(\boldsymbol{\mu g} / \mathbf{m l})$ & Analyst 1 & & Analyst 2 \\
\cline { 2 - 5 } & Area & Imiquimod & Area \\
\cline { 2 - 6 } & Salicylic acid & 371153 & Salicylic acid & Imiquimod \\
\hline $5,0.5$ & 193825 & 371303 & 198797 & 386815 \\
$5,0.5$ & 194588 & 371146 & 196176 & 384112 \\
$5,0.5$ & 193199 & 371200.6667 & 199484.3333 & 380535 \\
Mean & 193870.6667 & 88.69235223 & 3710.973502 & 383820.6667 \\
SD & 695.6251385 & 0.023893371 & 1.860283181 & 0.820727054 \\
\%RSD & 0.358808865 & & & \\
\hline
\end{tabular}

*Conc. = concentration, mean $\pm \mathrm{SD}, \mathrm{n}=3, \mathrm{SD}=$ standard deviation, $\% \mathrm{RSD}=$ relative standard deviation 


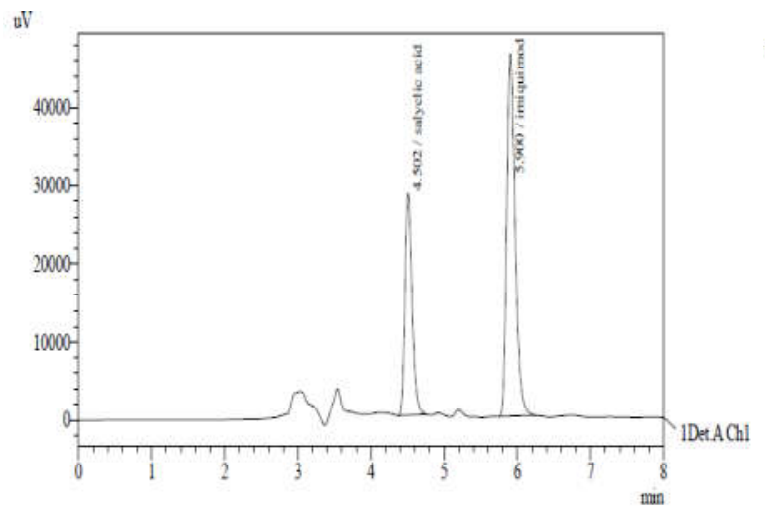

(A)

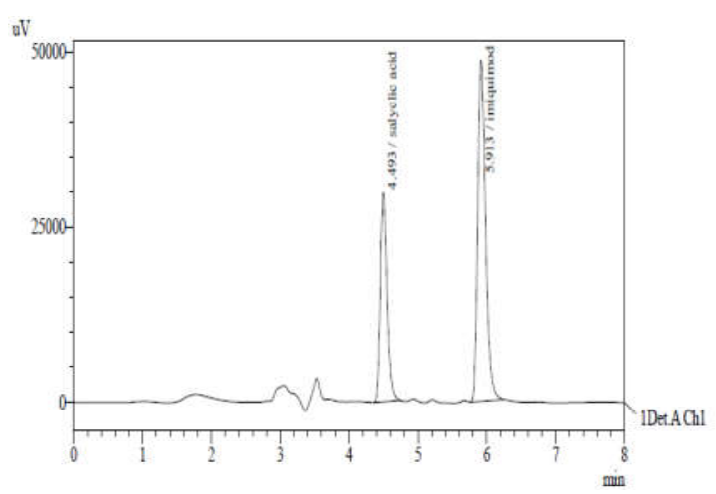

(B)

Fig. 10: Chromatogram of salicylic acid and imiquimod by analyst 1 (A) and analyst 2 (B)

Table 10: Specificity data of salicylic acid and imiquimod

\begin{tabular}{lll}
\hline Conc. $(\mu \mathrm{g} / \mathrm{ml})$ & Specificity \\
\cline { 2 - 3 } & Area & Imiquimod \\
\cline { 2 - 3 } & Salicylic acid & 336047 \\
$5,0.5$ & 189068 & 335741 \\
5.5 & 188871 & 333678 \\
Mean & 189556 & 335155.3 \\
SD & 189165 & 1288.524 \\
\%RSD & 352.6514 & 0.384456 \\
\hline
\end{tabular}

${ }^{*}$ Conc. $=$ concentration, mean $\pm \mathrm{SD}, \mathrm{n}=3, \mathrm{SD}=$ standard deviation, $\% \mathrm{RSD}=$ relative standard deviation

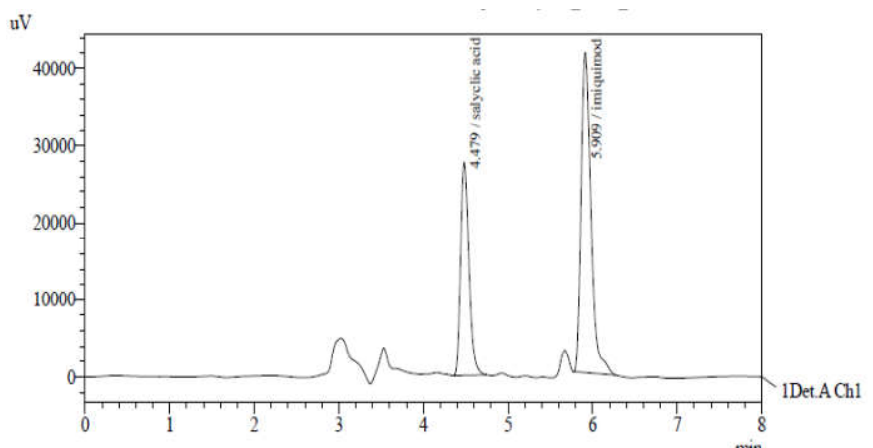

Fig. 11: Chromatogram of salicylic acid and imiquimod (specificity)

\section{CONCLUSION}

The RP-HPLC method was carried out on Nucleodur C18 $(250 \mathrm{~mm} \times$ $4.6 \mathrm{~mm}$ I.D., $5 \mu \mathrm{m}$ ) using low-pressure gradient elution mode. The limit of detection (LOD) and limit of quantification (LOQ) of salicylic acid was found to be $0.09756 \mu \mathrm{g} / \mathrm{ml}$ and $0.2956 \mu \mathrm{g} / \mathrm{ml}$, respectively, and imiquimod was found to be $0.044031 \mu \mathrm{g} / \mathrm{ml}$ and $0.13334 \mu \mathrm{g} / \mathrm{ml}$, respectively. The developed and validate method for imiquimod and salicylic acid was found to be sensitive, specific, and accurate and can be effectively applied for the simultaneous estimation of imiquimod and salicylic acid.

\section{ACKNOWLEDGMENT}

The Author is highly grateful to Dr. R. K Abhilashi, Chairman Abhilashi Group of Institutions, Mandi, India, for providing necessary facilities to carry out the research.

\section{FUNDING}

$\mathrm{Nil}$

\section{AUTHORS CONTRIBUTIONS}

All the author has contributed equally.

\section{CONFLICT OF INTERESTS}

Declared none

\section{REFERENCES}

1. Paula DD, Martins CA, Bentley MV. Development and validation of HPLC method for imiquimod determination in skin penetration studies. Biomed Chromatography 2008;22: 1416-23.

2. Hussain S, Shaikh T, Farooqui M. Development and validation of liquid chromatography method for the determination and quantification of impurities in imiquimod. J Pharm Res Int 2016;3:1-9.

3. Jain S, Diwan A, Sardana S. Development and validation of UV spectroscopy and RP-HPLC methods for estimation of imiquimod. Int J Pharm Sci Rev Res 2015;35:16-21. 
4. Tyring SK, Rosen T. Beyond a decade of $5 \%$ imiquimod topical therapy. J Drugs Dermatol 2009;8:467-74.

5. Madan RK, Levitt J. A review of toxicity from topical salicylic acid preparations. J Am Acad Dermatol 2014;70:788-92.

6. Bruner $\mathrm{CR}$, Feldman SR, Ventrapragada $\mathrm{M}$, Fleischer AB. A systematic review of adverse effects associated with topical treatments for psoriasis. Dermatol Online J 2003;9:2.

7. Scotter MJ, Roberts DP, Wilson LA, Howard FA, Davis J, Mansell $\mathrm{N}$. Free salicylic acid and acetylsalicylic acid content of foods using gas chromatography-mass spectrometry. Food Chem 2007;105:273-9.

8. Ekinci D, Şentürk M, Kufrevioglu OI. Salicylic acid derivatives: synthesis, features and usage as therapeutic tools. Expert Opin Ther Pat 2011;21:1831-41.

9. Chitlange SS, Imran M, Sakarkar DM. RP-HPLC method for simultaneous estimation of amlodipine and metoprolol in tablet formulation. Asian J Pharm 2008;2:232-4.

10. Kokot Z, Burda K. Simultaneous determination of salicylic acid and acetylsalicylic acid in aspirin delayed-release tablet formulations by second-derivative UV spectrophotometry. J Pharm Biomed Anal 1998;18(4 Suppl 5):871-5.

11. Guideline IH. Validation of analytical procedures: text and methodology Q2 (R1). International conference on harmonization, Geneva, Switzerland; 2005. p. 1-13.

12. Perlatti B, Maria Fd, Graças FdS, Fernandes JB, Ross M. Validation and application of HPLC-ESI-MS/MS method for the quantification of RBBR decolorization, a model for highly toxic molecules, using several fungi strains. Bio-Tech 2012 124:37-44.

13. Krier F, Michael B, Benjamin D, Pierre L, Aurelie D, Eric Z, et al. Optimisation and validation of a fast HPLC method for the quantification of sulindac and its related impurities. J Pharmaceut Biomed Anal 2011;54:694-70.

14. Gonzalez O, Iriarte G, Ferreiros N, Maguregui MI, Alonso RM, Jimenez RM. Optimization and validation of a SPE-HPLCPDA- fluorescence method for the simultaneous determination of drugs used in combined cardiovascular therapy in human plasma. J Pharmaceut Biomed 2009;50:630-9.

15. ICH Q2 (R1). Validation of analytical procedures: text and methodology. International Conference on Harmonization, IFPMA, Geneva; 2005.

16. Tranfo G, Enrico P, Renata S, Daniela P. Validation of an HPLC/MS/MS method with isotopic dilution for quantitative determination of trans, trans-muconic acid in urine samples of workers exposed to low benzene concentrations. J Chromatogr Biomed 2008;867:26-30.

17. Jenke DR. Chromatographic method validation: a review of current practices and procedures. Part II. Guidelines for primary validation parameters. Instrum Sci Technol 1998; 26:1-18.

18. Staes E, Rozet E, Ucakar B, Hubert P, Preat V. Validation of a method for the quantitation of ghrelin and unacylated ghrelin by HPLC. J Pharmaceut Biomed Anal 2010;51:633-9.

19. Patel BD, Bhavya Mehta, Chaudhary B Ankit. Method development and validation for simultaneous estimation of lamivudine and zidovudine in tablet by reverse-phase highperformance liquid chromatography. Asian J Pharm Clin Res 2020;13:73-7.

20. Rajan D Senthil, G Muruganathan, Shivkumar Kumutaavall, Thangavel Ganesh. Development and validation of hplc method for simultaneous quantification of vasicine, glycyrrhizin and piperine in poly herbal cough syrup. Int J Curr Pharm Res 2020;12:15-9.

21. Trani MTT, Katherine MP, Marlyn C. Matrix-specific method validation for quantitative analysis of vitamin $C$ in diverse foods. J Food Compost Anal 2012;26:12-25.

22. Hernandez YS, Sanchez LB, Bedia MMG, Luis TG. Determination of parthenin in Parthenium hysterophorus by means of HPLCUV: method development and validation. Phytochem Lett 2011;4:134. 